\title{
BDS Corporate Members
}

Anglian Water Services Ltd
Thorpe Wood House
Thorpe Wood
Peterborough
Cambridgeshire
PE3 6WT
Arup
Admiral House
78 East Street
Leeds
West Yorkshire
LS9 8EE
Atkins Limited
Woodcote Grove
Ashley Road
Essom
Surrey
KT18 5BW

Bachy Soletanche Ltd Henderson House

Langley Place

Burscough Industrial Estate

Burscough ir

Lancashire

L40 8JS

BAM Nuttall Ltd

St James House

Knoll Road

Camberle

Gurrey

Black \& Veatch

Grosvenor House

69 London Road

Redhill

Surrey
RH1 1LQ

Bristol Water plc

PO Box 218

Bridgewater Road

Bristol

BS99 7AU

British Waterways

64 Clarendon Road

64 Clarendor

Watford

WD17 1DA

Dam Safety Ltd

91B High Street

Arnersham

Buckinghamshire

HP7 ODT

Environment Agency

Manley House

Kestrel Way

Sowton Industrial Estate

Exeter

Devon

EX2 7LQ

ESB International Ltd

C E \& C E

Stephen Court

St Stephens Green

Dublin 2

Ireland

Halcrow Group Ltd

Burderop Park

Swindon

Wiltshire

SN4 OQD
Jacobs Engineering Group Inc Scottish Legal Life Building

95 Bothwell Street

Glasgow

Lanarkshire

Ganarkshire

Kenneth Grubb Associates Ltd

Wessex House

St Leonards Road

Bournemouth

Bournem
Dorset

BH8 8QS

Mott MacDonald Group

Demeter House

Station Road

Cambridge

Cambridgeshire

CB1 2RS

MWH Ltd

Terriers House

201 Amersham Road

High Wycombe

Buckinghamshire

HP13 5AJ

Scottish \& Southern Energy plc Inveralmond House

Inveralmond House

200 Dunkeld Road

Perth

Perthshire

PH1 3AQ

Scottish Water:

Glasgow North District

419 Balmore Road

Glasgow

Lanarkshire

G22 6NU

Severn Trent Water

Longbridge Office

Stratford Road

Warwick

CV34 6QW

Storm Geomatics Limited

Storm

Unit 28

Ditchford Farm
Nr. Moreton-in-Marsh

Nr. Moreton-in-M

Gloucestersh

Thames Water Utilities Ltd Clearwater Court (2nd Floor West) Vastern Road

Reading

RG1 8DB

United Utilities Water plc

Lingley Green Avenue

Great Sankey

Warringto

Cheshire

Yorkshire Water Inc

Reservoir Safety

Reservoir Safety
PO Box 500

Western House

Western House

Western Way

Bradford

BD6 2LZ

\section{Anglian Water Services Ltd}

CONTACT: Mike Cook

TELEPHONE: +44 (0)1223 542774

WEBSITE: www.anglianwater.co.uk

Anglian Water is geographically the largest water company in England and Wales, providing water and sewerage across East Anglia and the East Midlands as well as supplying water to the area around Hartlepool. Operating in the driest region of Britain with around $600 \mathrm{~mm}$ of rain in a year, the region's water resources are split equally between surface and groundwater sources. Anglian Water has 36 reservoirs under the Reservoirs Act with the most notable being Rutland, Grafham and Alton Water.

\section{Arup}

CONTACT: Peter Kelham

TELEPHONE: +44 (0)1132428498

WEBSITE: wWw.arup.com

Arup was formed in 1946 and is a global firm of consulting engineers, planners and scientists with a specialist water consultancy providing excellence in water and environmental engineering. Arup have a proven track record in the inspection, monitoring and supervision of existing reservoirs. Arup also have expertise in investigation, feasibility, design and construction supervision of new Arup also hell as the design of remedial and improvement works to existing dams. Dam projects dams, as well as the dis project have been undertakn worldwide for central and local government, international funding agencies, pivatisedwer. Arup has also guides on many aspects of dam and reservoir design and maintenance.

\section{Atkins Ltd}

CONTACT: Andy Hughes

TELEPHONE: +44 (0)1372 756287

WEBSITE: www.atkinsglobal.com

Atkins, the largest consultancy in the UK with more than 16000 staff worldwide, is an international, multi-disciplinary consultancy with over 100 years' experience of dam engineering. Atkins offers the full range of services associated with dam engineering including new dams for water supply, flood alleviation, river regulation, irrigation and hydropower, repairs and upgrade of existing dams, inspection and supervision under the Reservoirs Act 1975 both in the UK and overseas. Additional services are offered in risk assessment, particularly portfolio risk assessment, and training.

\section{Black \& Veatch Ltd}

CONTACT: Andy Rowland

TELEPHONE: +44 (0)1737 774155

WEBSITE: www.bv.com

The Black \& Veatch pre-eminence in dam and reservoir engineering includes over 100 years' experience in the UK, over 7000 professionals world-wide, dams to $200 \mathrm{~m}$ and $8000 \mathrm{MW}$ of hydropower under construction. All services are offered, from inspections to asset evaluations, and from design to EPC construction.

\section{Bristol Water plc \\ CONTACT: Colin Hunt}

TELEPHONE: +44 (0)1179665 881

WEBSITE: www. bristolwater.co.uk

Bristol Water plc, founded in 1846, supplies water to over one million people and businesses in an area of almost $2400 \mathrm{KM}^{2}$ centred on Bristol. It is a subsidiary of Sociedad General de Aguas de Barcelona S.A. (Agbar). The Agbar Group has subsidiaries in 19 countries, and provides services to more than 37 million people around the world.

\section{British Waterways}

CONTACT: David Brown

TELEPHONE: +44 (0)1926 626127

WEBSITE: www.britishwaterways.co.uk

British Waterways is a public corporation responsible to Defra and the Scottish Executive, owning and managing over $3000 \mathrm{~km}$ of waterways, comprising canal and river navigations, reservoirs and docks throughout the UK. British Waterways is responsible for 93 reservoirs, mostly built between 1773 and 1850 to supply water for the purposes of navigation. 


\section{Dam Safety Ltd}

CONTACT: Rod Bridle

TELEPHONE: +44 (0)1494 728833

WEBSITE: www.damsafety.co.uk

Dam Safety Ltd (formerly Rodney Bridle Ltd) has developed since its foundation in 1998 as an independent highly technical organisation specialising in dam safety engineering, particularly the performance of existing embankment dams. The new name, in addition to stating what we do, marks the beginning of our future as an organisation planning to grow organically, by merger and with associates to further assist dam owners to improve their dams and keep them safe. We are engaged in GB, the Isle of Man, Jersey and Ireland on a range of dam safety work including statutory inspections, design and construction, supervision of safety measures, review panels, reviews of performance and maintaining the safety of reservoirs while works are in progress in or close to the dams.

\section{Environment Agency}

CONTACT: Tony Deakin

TELEPHONE: +44 (0)8708 506506 (general enquiries on reservoir safety) +44 (0)800 807060 (Environment Agency emergency hotline)

E-MAlL: reservoirs@environment-agency.gov.uk.

WEBSITE: www.environment-agency.gov.uk/reservoirsafety

The Environment Agency is the enforcement authority for some 2100 reservoirs in England and Wales. Our role includes maintaining a register of reservoirs. It also involves making sure undertakers have their reservoirs regularly inspected and, when required, carry out essential safety works to reduce the risk of dam failure. We are legally required to report to Defra and the Welsh Assembly Government at regular intervals. This includes the submission of our biennial report, which outlines the actions we have taken to get undertakers to comply with the Reservoirs Act 1975 (the Act). It also documents the actions that, we have taken on reservoirs where we are the undertaker. In addition, Defra has charged us with the role of post-incident reporting. This involves maintaining a database of post-incident reports and the dissemination of the lessons learned from those reports to the reservoir industry. Overall compliance with the Act has improved since the Environment Agency became the enforcement authority in 2004. However, our experiences over the past three years have led us to conclude that a review of legislation covering reservoir safety is timely and we are currently working with the industry and government to achieve this aim.

\section{Halcrow Group Ltd}

CONTACT: Alan Warren/Jonathan Hinks

TELEPHONE: +44 (0)1793 812479

WEBSITE: www.halcrow.com

Halcrow Group Ltd offer a full consultancy service in the UK and overseas in the fields of dams and hydropower. In the UK we offer services in reservoir inspection, risk assessment, remedial works, improvement works, dambreak and emergency planning. We have a long history of dam construction in the UK and over the last five years we have provided services in connection with several hundred UK reservoirs including planning, design and/or construction supervision services for over 40 new reservoirs.

\section{Jacobs}

\section{CONTACT: Alan Brown}

TELEPHONE: +44 (0)1372 383533

WEBSITE: www.jacobs.com

Jacobs is one of the world's largest and most diverse providers of professional technical services. Our fundamental business strategy is building long-term client relationships to provide superior customer value, with over 90 percent of our work being repeat business. In the UK our permanent staff includes, six AR, one NI, and one SR Panel Engineers as well as eleven permanervising Engineers. This reflects our wide geographic and technical skills. All services are offered from inspection and asset management through to new dams and reservoirs both in the UK and internationally.

\section{Kenneth Grubb Associates Ltd (KGAL)}

KGAL offers a complete structural, mechanical and electrical engineering service, both in the UK and overseas, through all stages of a project from conceptual design development to final commissioning on site.

With more relevant staff years experience than any comparable company, KGAL are With more relevant staff years experience than any comparable company, KGAL are
recognised as the leaders in the field of Water Control Gate design, engineering and recognised as the leaders in the field of Water Control Gate design, engineering and
project management. With many of our engineers previously employed by the leading gate project management. With many of our engineers previously employed by the leading
design and build contractors of the time such as Armfield Engineering Ltd, Biwater design and build contractors of the time such as Armfield Engineering Ltd, Biwater
Hydropower, Newton Chambers Engineering (latterly Boving Newton Chambers, Kvaerner Boving and GE Hydro), we have a true working knowledge of gate design, manufacture and installation.

\section{Mott MacDonald Ltd}

CONTACT: Martin Airey

TELEPHONE: +44 (0)1223 463697

WEBSITE: www.mottmac.com

Mott MacDonald is a leading provider of dam engineering services with a growing portfolio of major projects both in the UK and overseas. We have been engaged in the study, design and construction of major dams and barrages for more than 80 years, providing a range of services including dam breach analysis, risk assessments, emergency planning, inspection, design and construction supervision on projects throughout the world covering all forms of dam construction.

\section{$\mathrm{MWH}$}

TELEPHONE: +44 (0)1494 526240

WEBSITE: www.mwhglobal.com

MWH has over 150 years' experience in dam engineering and offers full consultancy, planning and design services in the UK and across the world. MWH has been actively involved with the design and construction of more than 300 dams and reservoirs in the modern era. MWH has successfully completed numerous storage schemes for water supply, flood alleviation, river regulation and has been responsible for the design of over $50000 \mathrm{MW}$ installed capacity of hydropower.

\section{Severn Trent plc}

CONTACT: Ian Hope

TELEPHONE: 07774336430

E-MAIL: ian.hope@severntrent.co.uk

Severn Trent PIc is a leading FTSE 100 company. Our focus is on the provision, removal and treatment of water in the UK and internationally. We own and manage a fascinating stock of dams and have 59 reservoirs currently subject to the Reservoirs Act 1975.

\section{Storm Geomatics Limited}

CONTACT: Mike Hopkins

TELEPHONE: +44 (0)1608 664910

E-MAIL: mike.hopkins@storm-geomatics.com

WEBSITE: www.storm-geomatics.com

Storm Geomatics Limited is a specialist company that delivers high-quality measurement surveys to the water industry. Our surveyors understand the principles of water engineering and can reliably measure critical hydraulic features that influence a project. Data from site are then organised into a specified format, providing a seamless feed into the engineer's choice of software. If you need a reliable survey team that will understand your project and deliver the data you need, make the process easy for yourself and use a team from Storm Geomatics.

\section{Thames Water Utilities Limited}

CONTACT: Jon Green

TELEPHONE: +44 (0)7747 642651

WEBSITE: www thameswater co. $4 k$

Thames Water is the largest water and sewerage company in the UK, serving 13 millio customers in London and across the Thames Valley. The area we service covers $5000 \mathrm{~km}^{2}$, from parts of Kent and Essex in the east to the fringes of Gloucestershire in the west. Thames Water owns and operates 56 statutory dams and a further 450 smaller service reservoirs and flood storage areas throughout the Thames Water region.

\section{United Utilities Water plc}

CONTACT: Keith Gardiner

TELEPHONE: +44 (0)1925 537032

E-MAlL: keith.gardiner@uuplc.co.uk

WEBSITE: www.uuplc.com

United Utilities is the largest supply reservoir owner in England and Wales. We provide water and wastewater services to 7 million customers from Carlisle to Crewe and from the Pennines to the sea. We supply 2 billion litres of water a day, via 95 water treatment works and $40000 \mathrm{~km}$ of distribution mains, from sources which include 155 open reservoirs.

Corporate members are entitled to the inclusion of a short summary in the journal (up to 80 words). Please send these to the technical editor: andrew.kirby@mottmac.com. 